\title{
Prevalence of mould in chicken meat-cuts, giblets and products with immuno- affinity detection of aflatoxin residues
}

\author{
${ }^{1}$ Morshdy, A.E., ${ }^{2}$ Abdel Samie, A.A., ${ }^{1}$ Tharwat, A.E., ${ }^{2}$ Elshorbagy, I.M. and \\ $1,{ }^{*}$ Hussein M.A. \\ ${ }^{1}$ Food Control Department, Faculty of Veterinary Medicine, Zagazig University, Zagazig 44519, Egypt. \\ ${ }^{2}$ Animal health research institute Dokki 12619, Giza, Egypt.
}

\begin{abstract}
Article history:
Received: 3 February 2021

Received in revised form: 12

March 2021

Accepted: 2 April 2021

Available Online: 18 August 2021
\end{abstract}

\section{Keywords:}

Chicken burger,

Chicken luncheon,

Aflatoxin residues,

Lipolytic mould,

Proteolytic mould

DOI:

https://doi.org/10.26656/fr.2017.5(4).062

\begin{abstract}
Mould contamination and aflatoxin residues are considered big problems in the food chain, therefore 140 random samples of frozen chicken breast, thigh, gizzard, heart, liver, chicken burger, and chicken luncheon (twenty of each) were examined for detection of mould contamination level there proteolytic and lipolytic activity and aflatoxin residues in examined products. Mould colonies were detected in $100 \%$ and $30 \%$ of samples with mean values of $3.42 \pm 0.71$ and $1.29 \pm 0.30 \log _{10} \mathrm{CFU} / \mathrm{g}$ in the chicken burger and chicken luncheon, respectively. The identified species were Aspergillus 76/140 (54.3\%), Penicillium 39/140 (27.9\%), Alternaria 35/140 (25\%), Cladosporium 30/140 (21.4\%), Rhizopus13/140 (9.3\%), Acremonium 10/140 (7.1\%), Mucor 9/140 (6.4\%), Fusarium 7/140 (5\%) and Sporotricum 7/140 (5\%). Aspergillus niger, Aspergillus flavus, Aspergillus fumigatus, Aspergillus parasiticus, Aspergillus ochraceus and Aspergillus terrus were identified with total percentages of 53(37.9\%), 25(17.9\%), 21(15\%), 5(3.5\%), $5(3.5 \%)$ and $8(5.7 \%)$, respectively. The proteolytic and lipolytic activity detected in all species ranged between high, moderate and weak degrees except $A$. parasiticus shows only lipolytic activity. The examined samples had variable incidence and concentrations of aflatoxin residues as (20\%) $1.49 \pm 0.53$, (15\%) $1.89 \pm 0.89$, (55\%) $8.79 \pm 14$, (25\%) $1.64 \pm 0.38$, (20\%) $2.3 \pm 0.72$, (65\%) $9.21 \pm 1.12$ and $(35 \%) 4.12 \pm 0.68 \mu \mathrm{g} / \mathrm{kg}$ in frozen chicken breast, thigh, gizzard, heart, liver, chicken burger and chicken luncheon, respectively. Thus, strict hygienic measures during the production of chicken products must be adopted to minimize the deviation in their nutritional quality due to the growth of proteolytic and lipolytic mould, in addition, to protecting human health from the hazards of aflatoxin residues.
\end{abstract}

\section{Introduction}

The consumption of chicken meat products increased worldwide due to the high content of essential amino acids, and their competitive price. Chicken meat is considered a significant source of protein in Egypt due to the lack of red meat production (Hussein et al., 2018). Mould contamination of chicken meat products indicated bad sanitary and hygienic conditions adopted during the production cycle. Moreover, the growth of mould on the chicken product surfaces results in high economic losses and characterizes a hazard to human health due to the opportunity of aflatoxin production. Meat additives, such as spices, added during the formulation of chicken products can significantly increase the mould contamination of the chicken products (Gourama and Bullerman, 1995). The occurrence of aflatoxin in meat additive collected from Egypt at concentrations $2.01 \pm 0.45,4.14 \pm 1.17,0.64 \pm 0.24$ and $0.47 \pm 0.22 \mathrm{ppb}$ for red pepper, nutmeg, cumin and black pepper, respectively (El-Ghreeb et al., 2013). Furthermore, detected in luncheon, hot dog and corned beef with mean values of $10.14 \pm 0.3911 .5 \pm 0.63$ and $10.16 \pm 0.43 \mathrm{ppb}$, respectively (Algahtani et al., 2020). Enzymatic degradation is a natural process that occurs in meat after ageing and is enhanced due to temperature abuse (Tauro et al., 1986). Mould commonly produces extracellular proteases and lipases. Proteases (peptidases or proteolytic enzymes) can initiate and catalyse the hydrolysis of peptide bonds in protein. The cleavages of peptide bonds result in the degradation of protein into their original amino acids (Sabotič and Kos, 2012). Lipases have been studied for a number of moulds, primarily hyphomycetes, Zygomycetes, and yeasts. In 
meat, fat hydrolysis can occur enzymatically or nonenzymatically. The enzymatic hydrolysis of fats is termed fat deterioration (lipolysis) and is governed by lipases, esterases and phospholipase (Ghaly et al., 2010). Mycotoxicosis, which occurs in food as a result of the presence of $A$. flavus, is an example of "poisoning by natural means," and is therefore analogous to pathologies caused by heavy metals or pesticide residues. The clinical picture of mycotoxicosis mainly depends on the amount and duration of the exposure, type of mycotoxin, the age and health condition of the exposed person, genetics factors, dietary status, and interface with other toxic substances (Bennett and Klich, 2003). Aspergillus flavus and A. parasiticus fungi are mainly incriminated in Aflatoxins (AFs) production which defined as toxic metabolites, naturally occurring in food. AFs have been identified since the 1960s as significant contaminants by the agricultural production community and control strategies (Guo et al., 2000). Aspergillus flavus is responsible for the production of aflatoxin $\mathrm{B} 1$ and $\mathrm{B} 2$ (Wilson et al., 2002). Aflatoxin B1 has been classified as a "group 1 carcinogen", affecting the liver by International Agency for Research on Cancer (IARC, 1993). Once aflatoxin contaminates food cooking methods like Steaming as well as boiling caused a none significant reduction of aflatoxin level (Diedhiou et al., 2012). Thus, this study was conducted to estimate the prevalence of mould contamination in chicken meat cuts, giblets and products. Furthermore, identification of prevalent mould genera and their proteolytic and lipolytic activity was carried out. In addition, to the detection of aflatoxin residues in examined samples.

\section{Materials and methods}

\subsection{Samples collection and preparation}

A total of 140 random samples in frozen state $-18^{\circ} \mathrm{C}$ represented by chicken breast, thigh, gizzard, heart, liver, frozen chicken burger and cooked chicken luncheon stored at $4{ }^{\circ} \mathrm{C}$ (twenty of each) were collected from different localities in Zagazig city, Egypt. Samples were identified, packed then transferred refrigerated immediately to the Food Control Department Faculty of Veterinary Medicine Zagazig University, Egypt where mycological examinations were carried out. From each sample, $25 \mathrm{~g}$ were homogenized in $225 \mathrm{~mL}$ of sterile buffered peptone water $0.1 \%$ (APHA, 2001).

\subsection{Determination of the total mould count}

Total mould count (TMC) was estimated by culturing on duplicate plates of malt extract agar (Oxoid, MED 030) and Czapeck-Dox agar (HiMedia, M075). The plates were incubated at $25^{\circ} \mathrm{C}$ for $5-7$ days in the dark. The incubated plates were examined daily for the star shape mould growth, which is picked up under complete aseptic conditions with its surrounding medium and transferred into malt extract ager slope for further examination. TMC Estimated by counting both mould colonies on acidified malt extract agar and osmophilic moulds on Czapeck-Dox agar.

\subsection{Identification of isolated mould}

Mould is identified into genera depending on their micromorphological properties. In brief, the preserved isolates were subcultured on Czapeck- Dox agar and malt extract agar then, incubated at $25^{\circ} \mathrm{C}$ for 5-7 days. The identification of obtained colonies was carried out by observation and measurements of the macroscopical and microscopical characteristics carefully for identification according to Pitt and Hocking (2009).

\subsection{Evaluation of proteolytic and lipolytic activity of isolated mould}

Mould colonies cultivated on casein hydrolysis medium at $30^{\circ} \mathrm{C}$ for 7 days for estimation of proteolytic activity. Briefly, casein hydrolysis medium supplemented with skim milk (HIMEDIA, M763), which gives an opaque medium due to acid production, indicated by a clear zone surrounding the mould colony according to Paterson and Bridge, (1994). The lipolytic activity of mould was carried out on Tween 80 for 7 days at $30^{\circ} \mathrm{C}$ according to Ullman and Blasins, (1974). Positive lipolytic activity was noticed as opaque zone adjoining mould colony due to liberation of oleic acid by mould enzyme that, interact with calcium salt crystals.

\subsection{Quantitative detection of total aflatoxins}

Total aflatoxins $(\mathrm{B} 1+\mathrm{B} 2+\mathrm{G} 1+\mathrm{G} 2)$ estimated by fluorometer (VICAM. Series 4) twenty-five grams of ground samples with five grams of $\mathrm{NaCl}$ were extracted in hundred $\mathrm{mL}$ methanol: water $(80: 20)$ three times. The extracts were diluted four times with bi-distilled water and filtrated using glass microfibre filter, only four $\mathrm{mL}$ of filtrated extract at a rate of 1-2 drops/second passed through (AflaTest ${ }^{\circledR}-\mathrm{P}$ affinity column). One $\mathrm{mL}$ of HPLC grade methanol was used for elution of affinity column at a rate of one to two drops/second and finally collected in a glass cuvette. The AflaTest developer added $0.1 \mathrm{~mL}$ and mixed it well with the content of the cuvette then put the mixture in calibrated fluorometer followed by a reading of aflatoxin level after $1 \mathrm{~min}$. The limit of detection ranged from $0.1 \mathrm{ppb}$ to $300 \mathrm{ppb}$.

\subsection{Statistical analysis}

Mould counts were translated to CFU/g using base10 logarithms. After confirming normality with Shapirotest, Wilk's data was analysed using the one-way 
ANOVA method of SPSS v.23 (SPSS Inc., Chicago, Illinois, USA). To see if there were any major variations between mean values, Tukey's multiple comparison tests were used. The variance in the data was expressed as means s.e.m., and the alpha level for evaluating significance was set at 0.05 .

\section{Result and discussion}

\subsection{Mould count in examined samples}

Chicken meat may be contaminated with mould during slaughtering of the birds, transportation, or processing by the use of contaminated utensils or contaminated additives and spices, which are considered the most important source of mould contamination in chicken products (Jay et al., 2005). Moreover, inadequate cold preservation of chicken meat, giblets, and products may result in mould growth, especially, if the initial microbial load is high (Morshedy and Sallam, 2009). The mould colonies detected in all examined samples the highest percentage belongs to the frozen burger $(100 \%)$ and the lowest percentage was the share of luncheon (30\%) (Table 1). Mould previously detected within different percentages $(41 \%)$ of sausage samples collected from Italy (Iacumin et al., 2009); (65.7\%) and $(34.2 \%)$ for fresh and frozen chicken cuts collected from Nigeria (Ogu et al., 2017); (45\%) meat, (50\%) minced meat, (62.5\%) luncheon, (80\%) burger and (82.5\%) sausage samples collected from Egypt (Habashy et al., 2019). The existence of mould in most samples possibly suggests contamination of the environment where moulds are ubiquitous in air, soil, water, feeds and processing materials (Greco et al., 2014). Regarding total mould count in descending manner burger, gizzard, liver, heart, breast, thigh and luncheon contained $3.42 \pm 0.71$,
$2.89 \pm 0.68,2.85 \pm 0.62,2.23 \pm 0.46,1.92 \pm 0.42,1.84 \pm 0.39$ and $1.29 \pm 0.30 \quad \log _{10} \mathrm{CFU} / \mathrm{g}$, respectively (Table 1 ). Burger samples were significantly higher contaminated than other samples $(p<0.05)$ which attributed to the mixing of mould contaminated raw materials (chicken cuts, breading flours, starch and spices) that survive through processing steps. The obtained counts are nearly similar to Vural et al. (2013) (1- $\left.4.3 \log _{10} \mathrm{CFU} / \mathrm{g}\right)$ in frozen turkey collected from Turkey; Ogu et al. (2017) $\left(2.11-4.34 \log _{10} \mathrm{CFU} / \mathrm{g}\right)$ in fresh and frozen chicken collected from Nigeria.

\subsection{Mould identification}

Nine mould genera were isolated from examined samples in this study namely Aspergillus, Penicillium, Alternaria, Cladosporium, Rhizopus, Acremonium, Mucor, Fusarium, Sporotricum (Table 2). Aspergillus and Penicillium species were the commonly identified 18 $(90 \%)$ and $9(45 \%), 15(75 \%)$ and $8(40 \%), 12(60 \%)$ and $6(30 \%), 11(55 \%)$ and $7(35 \%), 9(45 \%)$ and 5 $(25 \%), 8(40 \%)$ and $3(15 \%), 3(15 \%)$ and $1(5 \%)$ in burger, liver, thigh, gizzard, breast, heart, luncheon, respectively (Table 2). Our finding substantiates with Darwish et al. (2016), Ogu et al. (2017) and Habashy et al. (2019) found that Aspergillus and Penicillium were the common mould genera isolated from chicken and meat samples. The frequent isolation of these two moulds attributed to the growth ability over $\mathrm{pH}$ ranged from 2 to 11 , the temperature ranged from -10 to $60^{\circ} \mathrm{C}$, water activity ranged from 0.620 to 0.995 and wide range of nutrient availability (Pitt and Hocking, 2009). The other identified species were Alternaria 25\%, Cladosporium 21.4\%, Rhizopus 9.3\%, Sporotricum $7.1 \%$, Mucor $6.4 \%$, Acremonium 5\% and Fusarium 5\% (Table 2). The isolated moulds in this study are usually

Table 1. Prevalence and count of mould $\left(\log _{10} \mathrm{CFU} / \mathrm{g}\right)$ of examined chicken meat, giblets and products $(\mathrm{n}=20)$.

\begin{tabular}{cccccccc}
\hline & Breast & Thigh & Liver & Heart & Gizzard & Burger & Luncheon \\
\hline Prevalence & $12(60 \%)$ & $14(70 \%)$ & $17(85 \%)$ & $13(65 \%)$ & $12(60 \%)$ & $20(100 \%)$ & $6(30 \%)$ \\
Minimum & 1.2 & 1 & 1.3 & 1 & 1.4 & 2.3 & 1 \\
Maximum & 2.8 & 2.9 & 3.4 & 3.2 & 3.8 & 4.3 & 1.8 \\
Mean \pm SD & $1.92 \pm 0.42^{\mathrm{bc}}$ & $1.84 \pm 0.39^{\mathrm{bc}}$ & $2.85 \pm 0.62^{\mathrm{b}}$ & $2.23 \pm 0.46^{\mathrm{bc}}$ & $2.89 \pm 0.68^{\mathrm{b}}$ & $3.42 \pm 0.71^{\mathrm{a}}$ & $1.29 \pm 0.30^{\mathrm{c}}$ \\
\hline
\end{tabular}

Values are presented as mean \pm SD. Values with different superscripts within each row are significantly different $(\mathrm{P}<0.05)$.

Table 2. Prevalence of mould genera in examined chicken meat, giblets and products.

\begin{tabular}{ccccccccc}
\hline & Breast & Thigh & Liver & Heart & Gizzard & Burger & Luncheon & Total \\
\hline Aspergillus & $9(45 \%)$ & $12(60 \%)$ & $15(75 \%)$ & $8(40 \%)$ & $11(55 \%)$ & $18(90 \%)$ & $3(15 \%)$ & $76(54.3 \%)$ \\
Penicillium & $5(25 \%)$ & $6(30 \%)$ & $8(40 \%)$ & $3(15 \%)$ & $7(35 \%)$ & $9(45 \%)$ & $1(5 \%)$ & $39(27.9 \%)$ \\
Alternaria & $4(20 \%)$ & $8(40 \%)$ & $6(30 \%)$ & $2(10 \%)$ & $5(25 \%)$ & $8(40 \%)$ & $2(10 \%)$ & $35(25 \%)$ \\
Cladosporium & $5(25 \%)$ & $3(15 \%)$ & $7(35 \%)$ & $4(20 \%)$ & $3(15 \%)$ & $7(35 \%)$ & $1(5 \%)$ & $30(21.4 \%)$ \\
Rhizopus & $2(10 \%)$ & - & $3(15 \%)$ & $1(5 \%)$ & $4(20 \%)$ & $3(15 \%)$ & - & $13(9.3 \%)$ \\
Sporotricum & $2(10 \%)$ & - & $3(15 \%)$ & $1(5 \%)$ & - & $4(20 \%)$ & - & $10(7.1 \%)$ \\
Mucor & - & $1(5 \%)$ & $2(10 \%)$ & $1(5 \%)$ & $2(10 \%)$ & $3(15 \%)$ & - & $9(6.4 \%)$ \\
Acremonium & - & $2(10 \%)$ & $3(15 \%)$ & - & - & $2(10 \%)$ & - & $7(5 \%)$ \\
Fusarium & - & $2(10 \%)$ & $1(5 \%)$ & - & $3(15 \%)$ & $1(5 \%)$ & - & $7(5 \%)$ \\
\hline
\end{tabular}


Table 3. Prevalence of Aspergillus species in examined chicken meat, giblets and products.

\begin{tabular}{lcccccccc}
\hline & Breast & Thigh & Liver & Heart & Gizzard & Burger & Luncheon & Total \\
\hline A. niger & $6(30 \%)$ & $7(35 \%)$ & $11(55 \%)$ & $5(25 \%)$ & $9(45 \%)$ & $13(65 \%)$ & $2(10 \%)$ & $53(37.9 \%)$ \\
A. flavus & $3(15 \%)$ & $2(10 \%)$ & $6(30 \%)$ & $2(10 \%)$ & $4(20 \%)$ & $6(35 \%)$ & $2(10 \%)$ & $25(17.9 \%)$ \\
A. fumigatus & $1(5 \%)$ & $3(15 \%)$ & $4(20 \%)$ & $3(15 \%)$ & $4(20 \%)$ & $5(25 \%)$ & $1(5 \%)$ & $21(15 \%)$ \\
A. parasiticus & - & - & - & - & $2(10 \%)$ & $3(15 \%)$ & - & $5(3.5 \%)$ \\
A. ochraceus & - & - & $2(10 \%)$ & - & $1(5 \%)$ & $2(10 \%)$ & - & $5(3.5 \%)$ \\
A. terrus & - & $1(5 \%)$ & $2(10 \%)$ & - & $1(5 \%)$ & $4(20 \%)$ & - & $8(5.7 \%)$ \\
\hline
\end{tabular}

Table 4. Lipolytic and proteolytic activities of the isolated mould.

\begin{tabular}{|c|c|c|c|c|c|c|c|c|c|}
\hline & \multirow{2}{*}{$\begin{array}{l}\text { No. of } \\
\text { tested }\end{array}$} & \multicolumn{4}{|c|}{ proteolytic } & \multicolumn{4}{|c|}{ Lipolytic } \\
\hline & & Positive & High & Moderate & weak & Positive & High & Medium & Weak \\
\hline A. niger & 53 & 42 & 11 & 29 & 2 & 46 & 44 & 2 & 0 \\
\hline A. flavus & 25 & 21 & 21 & 0 & 0 & 25 & 25 & 0 & 0 \\
\hline A. fumigatus & 21 & 13 & 11 & 2 & 0 & 16 & 1 & 5 & 10 \\
\hline A. parasiticus & 5 & 0 & 0 & 0 & 0 & 0 & 0 & 0 & 0 \\
\hline A. ochraceus & 5 & 4 & 0 & 1 & 3 & 4 & 0 & 2 & 2 \\
\hline A. terrus & 8 & 6 & 0 & 1 & 5 & 5 & 0 & 1 & 4 \\
\hline Penicillium sp. & 39 & 39 & 21 & 2 & 16 & 39 & 6 & 31 & 2 \\
\hline Alternaria sp. & 35 & 35 & 0 & 0 & 35 & 35 & 2 & 4 & 29 \\
\hline Cladosporium sp. & 30 & 22 & 0 & 18 & 4 & 30 & 0 & 2 & 28 \\
\hline Rhizopus sp. & 13 & 13 & 0 & 0 & 13 & 13 & 1 & 2 & 10 \\
\hline Sporotricum sp. & 10 & 4 & 0 & 1 & 3 & 7 & 0 & 3 & 4 \\
\hline Mucor sp. & 9 & 9 & 0 & 0 & 9 & 9 & 0 & 2 & 7 \\
\hline Acremonium sp. & 7 & 5 & 0 & 2 & 3 & 7 & 2 & 3 & 2 \\
\hline Fusarium sp. & 7 & 6 & 0 & 1 & 5 & 6 & 0 & 3 & 3 \\
\hline
\end{tabular}

present in air water and soil and able to contaminate food if it is poorly processed (Źukiewicz-Sobczak et al., 2015). Aspergillus species could be identified into $A$. niger, A. flavus, A. fumigatus, $A$. parasiticus, $A$. ochraceus and $A$. terrus with total percentages of 53 (37.9\%), 25 (17.9\%), 21 (15\%), 5 (3.5\%), 5 (3.5\%) and 8 (5.7\%), respectively (Table 3 ). The finding is in agreement with Darwish et al. (2016) who isolate $A$. niger and A. flavus from chicken meat samples retailed in Egypt and Zakki et al. (2017) who detected A. niger, A. fumigates and A. flavus in chicken meat collected from Pakistan.

\subsection{Proteolytic and lipolytic activity of isolated mould}

The ability of isolated mould to exhibits their proteases and lipases were examined, all Aspergillus species have the ability to produce proteases and lipases between high, moderate and weak degree except $A$. parasiticus. Furthermore, proteolytic and lipolytic activity was detected in all examined Penicillium, Alternaria, Rhizopus, Mucor species (Table 4). Certain mould strains of Penicillium and Mucor isolated from cold meats have ability to produce proteolytic and lipolytic activity against meat proteins and lipid both in vitro and in processed meat (Trigueros et al., 1995; Toledo et al., 1997). Additionally, the proteolytic and lipolytic activity previously detected in $52.70 \%$ and $94.59 \%$ of mould isolated from dry-cured ham (Alapont et al., 2015); $82.4 \%$ and $88.9 \%$ of examined mould isolated from meat products have proteolytic and lipolytic activity (Habashy et al., 2019). The fungi that produce proteolytic and lipolytic enzymes have two ways, the first good directions; play an important role in the appearance of favourable flavour to the consumer of some meat products as dry-cured ham and sausage (Flores et al., 1997; Marušić et al. 2011). The worse direction, in frozen meat and chicken, leading to depletion in the nutritional quality of chicken products and changes in sensory characteristics (Wigmann et al., 2015).

\subsection{Aflatoxin residues in examined samples}

Total aflatoxin residues estimated in the examined burger $(9.21 \pm 1.12 \mu \mathrm{g} / \mathrm{kg})$ and liver $(8.79 \pm 14 \mu \mathrm{g} / \mathrm{kg})$ was significantly higher $(\mathrm{P}<0.05)$ than other examined samples (Table 5). Parallel reports of aflatoxin occurrence in marketed poultry meat and giblets, $38 \%$ of broiler chicken meat samples were contaminated with aflatoxin the highest level was found in the liver $3.40 \pm$ $1.01 \mu \mathrm{g} / \mathrm{kg}$ in Pakistan (Iqbal et al., 2014). In Mozambique, the level of contamination with aflatoxin B1 was 39\% (0.57-3.80 $\mu \mathrm{g} / \mathrm{kg})$ for liver and $13.8 \%(0.68$ - $2.12 \mu \mathrm{g} / \mathrm{kg}$ ) for gizzard (Sineque et al., 2017). Much lower aflatoxins contamination were reported in Egypt by Abd-Elghany and Sallam (2015) they detected $1.12 \pm 0.10$ and $3.22 \pm 0.43 \mu \mathrm{g} / \mathrm{kg}$ for beef luncheon and 
Table 5. Aflatoxin residues $(\mu \mathrm{g} / \mathrm{kg})$ of examined chicken meat, giblets and products in comparison with legal limits $(\mathrm{n}=20)$.

\begin{tabular}{lccccccc}
\hline & Breast & Thigh & Liver & Heart & Gizzard & Burger & Luncheon \\
\hline Prevalence & $4(20 \%)$ & $3(15 \%)$ & $11(55 \%)$ & $5(25 \%)$ & $4(20 \%)$ & $13(65 \%)$ & $7(35 \%)$ \\
Minimum & 0.12 & 0.16 & 2.13 & 0.13 & 0.14 & 2.84 & 1.16 \\
Maximum & 2.66 & 3.16 & 16.12 & 2.13 & 3.16 & 15.11 & 6.38 \\
Mean \pm SD & $1.49 \pm 0.53^{\mathrm{b}}$ & $1.89 \pm 0.89^{\mathrm{b}}$ & $8.79 \pm 14^{\mathrm{a}}$ & $1.64 \pm 0.38^{\mathrm{b}}$ & $2.3 \pm 0.72^{\mathrm{b}}$ & $9.21 \pm 1.12^{\mathrm{a}}$ & $4.12 \pm 0.68^{\mathrm{ab}}$ \\
Within PL 20 $^{*}$ & $20(100 \%)$ & $20(100 \%)$ & $20(100 \%)$ & $20(100 \%)$ & $20(100 \%)$ & $20(100 \%)$ & $20(100 \%)$ \\
Exceeded PL20 & 0 & 0 & 0 & 0 & 0 & 0 & 0 \\
Within PL4 $^{*}$ & $20(100 \%)$ & $20(100 \%)$ & $11(55 \%)$ & $20(100 \%)$ & $20(100 \%)$ & $9(45 \%)$ & $16(80 \%)$ \\
Exceeded PL4 $^{\#}$ & 0 & 0 & $9(45 \%)$ & 0 & 0 & $11(55 \%)$ & $4(20 \%)$ \\
\hline
\end{tabular}

Values are presented as mean \pm SD. Values with different superscripts within each row are significantly different $(\mathrm{P}<0.05)$. *FDA (2000), ${ }^{\#}$ FAO (2004).

beef burger, respectively. While higher residue level $(11.10 \mu \mathrm{g} / \mathrm{kg})$ was detected in beef luncheon (Ismail and Zaky, 1999) and much higher residue $(150 \mu \mathrm{g} / \mathrm{kg})$ was obtained in kubeba (Aziz and Youssef, 1991) in Egypt. Conversely, much lower aflatoxins $(0.05 \mu \mathrm{g} / \mathrm{kg})$ were obtained in French delicatessen meats (Sirot et al., 2013). The high level of aflatoxin residues in burger samples may be due to many sources of mould contamination, which could be introduced from the direct growth of moulds in the surface of meat products, or indirectly from non-meat additives that were previously contaminated with aflatoxin, such as spices and cereals, which are used in the formulation of chicken products as a main ingredient (European Commission, 2002). Moreover, higher aflatoxin levels in the liver are attributed to the role of the liver in detoxification of aflatoxin, to protect the body against their toxic effects (Fouad et al., 2019).

Human all over the world may be exposed to potential health hazards due to consumption of mycotoxin, Maximum residue limit for aflatoxins in commodities have been assessed worldwide. The maximum threshold limit of $20 \mu \mathrm{g} / \mathrm{kg}$ for aflatoxins in foods has been established (FDA, 2000), while a limit of $4 \mu \mathrm{g} / \mathrm{kg}$ has been established for foods (FAO, 2004). On holding comparisons for aflatoxin with the established regulation of Food and Drug Administration (FDA, $2000)$ we found all examined samples (100\%) within the maximum permissible limits $(20 \mu \mathrm{g} / \mathrm{kg})$. Meanwhile, comparison with a permissible limit of $4 \mu \mathrm{g} / \mathrm{kg}$ set by the Food and Agriculture Organization (FAO, 2004) we found $9 / 20(45 \%), 11 / 20(55 \%)$ and 4/20 (20\%) of liver, burger and luncheon, respectively (Table 5). It is, therefore, possible that chicken meat, giblets, and products tested may exist as a hazard to consumers and aflatoxin levels must be examined more broadly to protect human health.

\section{Conclusion}

Chicken meat cuts, giblets and products contaminated with proteolytic and lipolytic mould which affect the quality in addition to the occurrence of aflatoxin residues that constitutes a public health hazard for consumer. So following the steps of the food safety management system can be a good solution to maintain the health and safety of the consumer.

\section{Conflict of interest}

The authors declare no conflict of interest.

\section{References}

Abd-Elghany, S.M. and Sallam, K.I. (2015). Rapid determination of total aflatoxins and ochratoxins A in meat products by immuno-affinity fluorimetry. Food Chemistry, 179, 253-256. https:// doi.org/10.1016/j.foodchem.2015.01.140

Alapont, C., Martínez-Culebras, P.V. and LópezMendoza, M.C. (2015). Determination of lipolytic and proteolytic activities of mycoflora isolated from dry-cured teruel ham. Journal of Food Science and Technology, 52(8), 5250-5256. https:// doi.org/10.1007/s13197-014-1582-5

Algahtani, F.D., Morshdy, A.E., Hussein, M.A., Abouelkheir, E.S., Adeboye, A., Valentine, A. and Elabbasy, M.T. (2020). Biogenic Amines and Aflatoxins in Some Imported Meat Products: Incidence, Occurrence, and Public Health Impacts. Journal of Food Quality, 1(3), 1-7. https:// doi.org/10.1155/2020/8718179

APHA (2001). (American Public Health Association) Compendium of methods for the microbiological examination of foods. $4^{\text {th }}$ Ed. In Downes, F.P. and Ito, K. (eds). Washington D.C., USA: Sheridan Books Inc.

Aziz, N.H. and Youssef, Y.A. (1991). Occurrence of aflatoxins and aflatoxin-producing moulds in fresh and processed meat in Egypt. Food Additives and Contaminants, 8(3), 321-331. https:// doi.org/10.1080/02652039109373981 
Bennett, J. and Klich, M. (2003). Mycotoxins. Clinical Microbiology Reviews, 16(3), 497-516. https:// doi.org/10.1128/CMR.16.3.497-516.2003

Darwish, W.S., Bayomi, R.M.E., El-Moaty, A.M.A. and Gad, T.M. (2016). Mould contamination and aflatoxin residues in frozen chicken meat-cuts and giblets. Japanese Journal of Veterinary Research, 64 (Supplement 2), S167-S171.

Diedhiou, P.M., Ba, F., Kane, A. and Mbaye, N. (2012). Effect of different cooking methods on aflatoxin fate in peanut products. African Journal of Food Science and Technology, 3(12), 53-58.

El-Ghareeb, W.R., Darwish, W.S., Tharwat, A.E., ElDesoky, K.I. and Hussein, M.A. (2013). Aflatoxin and ochratoxin A residues in some meat additives. Life Science Journal, 10(4), 3411-3417.

European Commission (2002). Reports on tasks for scientific cooperation. Reports of experts participating in Task 3.2.7. Assessment of dietary intake of ochratoxin A by the population of EU Member States, SCOOP Task 3.2.7, January 2002.

Food and Agriculture Organization (FAO). (2004). Worldwide regulations for mycotoxins in food and feed in 2003. Food and Nutrition Paper, FAO, Rome. Paper 81.

FDA. (2000). Guidance for industry: Action levels for poisonous or deleterious substances in human food and animal feed. Retrieved from http://www.fda.gov/ Food/ Guidance Compliance Regulatory Information /GuidanceDocuments/ ChemicalContaminantsandPesticides/ ucm077969.htm\#afla

Flores, M., Aristoy, M.C., Spanier, A.M. and Toldrá, F. (1997). Non-volatile components effects on quality of "Serrano" dry-cured ham as related to processing time. Journal of Food Science, 62(6), 1235-1239. https://doi.org/10.1111/j.1365-2621.1997.tb12252.x

Fouad, A.M., Ruan, D., El-Senousey, H.K., Chen, W., Jiang, S. and Zheng, C. (2019). Harmful effects and control strategies of aflatoxin b1 produced by Aspergillus flavus and Aspergillus parasiticus strains on poultry. Toxins, 11(3), 176. https:// doi.org/10.3390/toxins 11030176

Ghaly, A.E., Dave, D., Budge, S. and Brooks, M.S. (2010). Fish spoilage mechanisms and preservation techniques. American Journal of Applied Sciences, 7 (7), $\quad$ 859-877. https://doi.org/10.3844/ ajassp.2010.859.877

Gourama, H. and Bullerman, L.B. (1995). Aspergillus flavus and Aspergillus parasiticus: Aflatoxigenic fungi of concern in foods and feeds: A review. Journal of Food Protection, 58(12), 1395-
1404. https://doi.org/10.4315/0362-028X-58.12.1395

Greco, M.V., Franchi, M.L., Rico Golba, S.L., Pardo, A.G. and Pose, G.N. (2014). Mycotoxins and mycotoxigenic fungi in poultry feed for foodproducing animals. The Scientific World Journal, 1, 1-9. https://doi.org/10.1155/2014/968215

Guo, B.Z., Widstrom, N.W., Cleveland, T.E. and Lynch, R.E. (2000). Control of preharvest aflatoxin contamination in corn: Fungus-plant-insect interactions and control strategies. Recent Research Developments in Agricultural and Food Chemistry, 4 (1), 165-176.

Habashy, A.H.A., Darwish, W.S., Hussein, M.A. and ElDien, W.M.S. (2019). Prevalence of different mould genera in meat and meat products with some reduction trials using essential oils. Advances in Animal and Veterinary Sciences, 7(s2), 79-85.

Hussein, M.A., El-Ghareeb, W.R. and Nasr, M.A. (2018). The effect of rosemary extract and lactic acid on the quality of refrigerated broiler fillets. Journal of Food Science and Technology, 55(12), 5025-5034. https://doi.org/10.1007/s13197-018-3441-2

Iacumin, L., Chiesa, L., Boscolo, D., Manzano, M., Cantoni, C., Orlic, S. and Comi, G. (2009). Moulds and ochratoxin $\mathrm{A}$ on surfaces of artisanal and industrial dry sausages. Food Microbiology, 26(1), 65-70. https://doi.org/10.1016/j.fm.2008.07.006

International Agency for Research on Cancer (IARC). (1993). Ochratoxin A. Some naturally occurring substances: Food items and constituents, heterocyclic aromatic amines and mycotoxins. IARC Monograph on the Evaluation of Carcinogenic Risk to Humans. Lyon, 56, 489-521.

Iqbal, S.Z., Nisar, S., Asi, M.R. and Jinap, S. (2014). Natural incidence of aflatoxins, ochratoxin A and zearalenone in chicken meat and eggs. Food Control, 43, 98-103. https://doi.org/10.1016/ j.foodcont.2014.02.046

Ismail, M.A. and Zaky, Z.M. (1999). Evaluation of the mycological status of luncheon meat with special reference to aflatoxigenic moulds and aflatoxin residues. Mycopathologia, 146(3), 147-154. https:// doi.org/10.1023/A:1007086930216

Jay, J.M., Leossner, M.J. and Golden, D.V. (2005). Modern food microbiology. $7^{\text {th }}$ Ed. Chapter 2, taxonomy, role and significance of microorganisms in foods. p. 13-37. Springer Science. https:// doi.org/10.1007/978-94-011-6480-1_2

Marušić, N., Petrović, M., Vidaček, S., Petrak, T. and Medić, H. (2011). Characterization of traditional Istrian dry-cured ham by means of physical and chemical analyses and volatile compounds. Meat 
Science, 88(4), 786-790. https://doi.org/10.1016/ j.meatsci.2011.02.033

Morshedy, A.M. and Sallam, K.I. (2009). Improving the microbial quality and shelf life of chicken carcasses by trisodium phosphate and lactic acid dipping. International Journal of Poultry Science, 8 (7), 645-650. https://doi.org/10.3923/ ijps.2009.645.650

Ogu, G.I., Madar, I.H., Igborgbor, J.C. and Okolo, J.C. (2017). Mycological Quality of Fresh and Frozen Chicken Meat Retailed within Warri Metropolis, Delta State, Nigeria. Jordan Journal of Biological Sciences, 10(4), .308-303

Paterson, R.R.M and Bridge, P.D. (1994). Biochemical techniques for filamentous fungi. International Mycological Institute, Bakeham Lane, Egham TW20 9TY, UK: pp.21.

Pitt, J.I. and Hocking, A.D. (2009). Fungi and Food Spoilage, $3^{\text {rd }}$ Ed. London: Blackie Academic and Professional Academic Press New York. https:// doi.org/10.1007/978-0-387-92207-2

Sabotič, J. and Kos, J. (2012). Microbial and fungal protease inhibitors - current and potential applications. Applied Microbiology and Biotechnology, 93(4), 1351-1375. https:// doi.org/10.1007/s00253-011-3834-x

Sineque, A.R., Macuamule, C.L. and Dos Anjos, F.R. (2017). Aflatoxin B1 contamination in chicken livers and gizzards from industrial and small abattoirs, measured by ELISA technique in Maputo, Mozambique. International Journal of Environmental Research and Public Health, 14(9), 951-960. https://doi.org/10.3390/ijerph14090951

Sirot, V., Fremy, J.M. and Leblanc, J.C. (2013). Dietary exposure to mycotoxins and health risk assessment in the second French total diet study. Food and Chemical Toxicology, 52, 1-11. https:// doi.org/10.1016/j.fct.2012.10.036

Tauro, P., Kapoor, K.K. and Yadav, K.S. (1986). An introduction to microbiology. $1^{\text {st }}$ edn. New Delhi, India: New Age International Publishers.

Toledo, V.M., Selgas, M.D., Casas, M.C., García, M.L. and Ordóñez, J.A. (1997). Effect of selected mould strains on proteolysis in dry fermented sausages. ZeitschriftürLebensmitteluntersuchung und-Forschung A, 204(5), 385-390. https:// doi.org/10.1007/s002170050095

Trigueros, G., García, M.L., Casas, C., Ordóñez, J.A. and Selgas, M.D. (1995). Proteolytic and lipolytic activities of mould strains isolated from Spanish dry fermented sausages. Zeitschriftfür LebensmittelUntersuchung und Forschung, 201(3), 298-302.
https://doi.org/10.1007/BF01193008

Ullman, V. and Blasins, G. (1974). A simple medium for the detection of different lipolytic activity of microorganisms. ZentralblattfürBakteriologie, Mikrobiologie and Hygiene. Abt A 299, 264-267.

Vural, A., Erkan, M.E., Guran, H.S. and Durmusoglu, H. (2013). A study about microbiological quality and species identification of frozen turkey meat. International Journal of Nutrition and Food Sciences, 2(6), 337-341. https://doi.org/10.11648/ j.ijnfs.20130206.22

Wigmann, E.F., Saccomori, F., Bernardi, A.O., Frisvad, J.C. and Copetti, M.V. (2015). Toxigenic penicillia spoiling frozen chicken nuggets. Food Research International, 67, 219-222. https://doi.org/10.1016/ j.foodres.2014.11.025

Wilson, M.D., Mubatanhema, W. and Jurjevic, Z. (2002). Biology and ecology of mycotoxigenic Aspergillus species as related to economic and health concerns. Advances in Experimental Medicine and Biology, 504, 3-17. https://doi.org/10.1007/978-14615-0629-4_2

Zakki, S.A., Qureshi, R., Hussain, A., Ghias, W., Sharif, M. and Ansari, F. (2017). Microbial quality evaluation and prevalence of bacteria and fungus in different varieties of chicken meat in Lahore. RADS Journal of Pharmacy and Pharmaceutical Sciences, 5(1), 30-37.

Żukiewicz-Sobczak, W., Cholewa, G., Sobczak, P., Zagórski, J. and Wojtyła-Buciora, P. (2015). Health risks associated with exposure to fungi. Agriculture and Agricultural Science Procedia, 7, 313-317. https://doi.org/10.1016/j.aaspro.2015.12.053 